\title{
An Examination of Instructional High School Chemistry Videos on EBA Portal in terms of Nine Events of Instruction
}

\author{
Güneş Uğraş* \\ Computer Education and Instructional Technology, Yüzüncü Yll Üniversitesi, Van, \\ Turkey
}

\author{
Ahmet Murat Uzun \\ Computer Education and Instructional Technology, Afyon Kocatepe University, \\ Afyonkarahisar, Turkey
}

\begin{abstract}
Ali Battal
Computer Education and Instructional Technology, Middle East Technical University, Ankara, Turkey

\section{Halil Kayaduman}

Computer Education and Instructional Technology, Middle East Technical University, Ankara, Turkey
\end{abstract}

\begin{tabular}{ll}
\hline \hline Article history & The purpose of this study is to examine the instructional high school \\
Received: & chemistry videos on EBA in line with Gagne's nine events of instruction. \\
10.03.2016 & Content analysis was used to examine the chemistry videos on EBA are \\
appropriate in accordance with Gagne's nine events of instruction. & Content analysis can be conducted in both quantitative and qualitative \\
24.03 .2016 & ways. Hence, a quantitative media content analysis was adopted as a \\
& method of design considering the aim of study. Four instructional \\
Accepted: & designers, who are experts in the field, evaluated the appropriateness of \\
29.03 .2016 & the instructional videos. Two different equal groups were formed. Both of \\
Key words: & them independently evaluated the qualities of the videos according to the \\
EBA, nine events of & phases of Gagne's Nine Events of Instruction. A scoring rubric was \\
instruction, instructional video & developed by the researchers in order to evaluate the quality of each \\
& video on the basis of those phases. Each learning phase in the \\
& instructional videos were checked and scored by the experts. Findings \\
& indicated that there was a certain need to improve the quality of \\
chemistry videos on EBA website. Consequently, the instructional videos & on EBA found not good enough to promote a positive attitude towards \\
the chemistry class, because some phases of the nine events of instruction & are missing or needs to be improved. \\
\hline \hline
\end{tabular}




\section{Introduction}

In conjunction with globalization and rapid advancements in technology, people in almost all areas have been affected, and subsequently a transformation process has begun. In line with this transformation, obviously, educational settings have also added to the process to fulfil the requirements of the age we are in. At this point, schools have been the centers of society; students, teachers and stakeholders have become important contributors of these communities. Considering the importance of it, countries started to allocate big budgets to increase the effectiveness of education. In this regard, one of the focuses is Information Communication Technologies (ICT). To explain the reason why ICT is being invested so much, let's look at the literature in this field first. For example; Godfrey (2001) says that integrating ICT into education can provide rich and flexible learning environments. In such environments, students can decide what, when and how to study, work/study at their own pace, and in return more effective learning can occur. By doing so; countries can run schools as they are the learning centers of society, and they can keep up with this transformation process more easily.

Recently, a very big budget project, Movement of Enhancing Opportunities and Improving Technology (FATIH), started to be conducted in Turkey. For this purpose, the Ministry of National Education (MEB) and Ministry of Transportation and Communication signed contracts to carry out this project together across Turkey. It is projected that almost twenty billion Turkish Liras (more than 11 billion US dollars today) is going to be invested to complete this project. The project was released to public in November 2010 and is still being applied. In the context of FATIH project, 42.000 schools and 570.000 classes are going to be equipped with the latest information technologies. The purpose is to provide ICT equipment to support teaching and learning processes. There are five components of this project (MEB, 2013). These are;

- Hardware Infrastructure,

- E-content,

- The effective usage of IT in classrooms,

- In-service teacher training programs,

- Network Infrastructure.

As it can be seen, there are several components. Due to investing a big amount of money for the project, each step should be carefully planned to attain the goals accurately. One of these components is to provide e-content for the K-12 curriculum. Providing an instructional e-content is really important for the process of ICT integration. Without having them, teachers and students may not benefit from the advantages of such a large project, and it will result a big loss for the country and its educational system. To do it so; MEB developed a web site to provide e-contents for teachers and students to benefit from. *The name of the web site is Information Network in Education (Eğitimde Bilişim Ağı), shortly EBA.

EBA is an online web portal consisting of many modules developed by the Ministry of National Education. The aim of this portal is to provide and support the use of instructional materials by using information and communication technologies at home, in school or in any place when needed (EBA, 2013). EBA portal consists of many modules; news module which informs teachers and students' studies to others all around the country, e-book module which includes online format of course books, audio and visual modules which offer many audio files and visuals to users, discussion module in 
which teachers and students share their ideas and video module which includes a variety of videos. It does not only offer instructional videos from chemistry to literature but also offers documentaries, cartoons, career development and guidance videos. The content of EBA portal is provided by voluntary brands, teachers and students. Shortly, EBA was established in order to provide; a rich educational content, create a common ground among teachers and students, and a social network to exchange the information among users.

According to the statistics of EBA, there were more than two hundred and fifty thousand registered users, forty five thousand visuals and two and half thousand videos on EBA portal when this study was being conducted (EBA, 2013). The videos on the EBA portal can be categorized under two topics: instructional videos and noninstructional videos. Non-instructional videos constitute almost one out of third of the videos consisting of documentaries, cartoon, national anthems, news, and help videos and so on. Instructional videos consist of several videos related to mathematics, science and technology, Turkish language, foreign language (English), and other courses from K1 to K12 grade levels. Since the aim of this study is focuses on instructional videos, only the instructional videos were elaborated. Table 1 shows the number of videos in each course offered, according to the grade level.

As it can be seen from the Table 1 below, there are many videos that have been developed to be used for educational activities. To benefit more from these videos on EBA, they should be prepared in an appropriate way to help students and teachers improve their learning and teaching about lessons. This is because; examination of videos becomes important to guide practitioner to see the current situation and if necessary, help them prepare these videos in a more appropriate way.

Table 1. The number of videos according to grade level on EBA

\begin{tabular}{|c|c|c|c|c|c|c|}
\hline Grade & Lesson & No. & Lesson & No. & Lesson & No. \\
\hline $1^{\text {th }}$ & Social Studies & 10 & & & & \\
\hline $2^{\text {nd }}$ & Mathematics & 14 & Turkish & 6 & Social Studies & 10 \\
\hline $3^{\text {th }}$ & Mathematics & 16 & Social Studies & 21 & & \\
\hline $4^{\text {th }}$ & Mathematics & 5 & & & & \\
\hline $5^{\text {th }}$ & $\begin{array}{l}\text { Mathematics } \\
\text { Science and Technology }\end{array}$ & $\begin{array}{l}6 \\
12\end{array}$ & Turkish & 9 & Religion and Ethics & 25 \\
\hline $6^{\text {th }}$ & Science and Technology & 14 & & & & \\
\hline $7^{\text {th }}$ & $\begin{array}{l}\text { Science and Technology } \\
\text { English Language }\end{array}$ & $\begin{array}{l}7 \\
14 \\
\end{array}$ & Germany language & 12 & French language & 12 \\
\hline $8^{\text {th }}$ & Mathematics & 12 & French language & 12 & English Language & 12 \\
\hline $9^{\text {th }}$ & $\begin{array}{l}\text { Mathematics } \\
\text { Geometry } \\
\text { Chemistry } \\
\text { Geography }\end{array}$ & $\begin{array}{l}52 \\
15 \\
85 \\
53\end{array}$ & $\begin{array}{l}\text { History } \\
\text { Literature } \\
\text { Germany language }\end{array}$ & $\begin{array}{l}18 \\
16 \\
5\end{array}$ & $\begin{array}{l}\text { English language } \\
\text { Religion and Ethics } \\
\text { Grammar }\end{array}$ & $\begin{array}{l}18 \\
10 \\
20\end{array}$ \\
\hline $10^{\text {th }}$ & $\begin{array}{l}\text { Mathematics } \\
\text { Biology } \\
\text { Chemistry } \\
\end{array}$ & $\begin{array}{l}33 \\
28 \\
65 \\
\end{array}$ & $\begin{array}{l}\text { English language } \\
\text { Germany language } \\
\text { Literature }\end{array}$ & $\begin{array}{l}14 \\
6 \\
14 \\
\end{array}$ & $\begin{array}{l}\text { Geography } \\
\text { Grammar }\end{array}$ & $\begin{array}{l}5 \\
21\end{array}$ \\
\hline $11^{\text {th }}$ & $\begin{array}{l}\text { Mathematics } \\
\text { Biology }\end{array}$ & $\begin{array}{l}25 \\
6 \\
\end{array}$ & Physics & 5 & Geography & 4 \\
\hline $12^{\text {th }}$ & $\begin{array}{l}\text { Mathematics } \\
\text { Physics }\end{array}$ & $\begin{array}{l}12 \\
10 \\
\end{array}$ & $\begin{array}{l}\text { Chemistry } \\
\text { Geography }\end{array}$ & $\begin{array}{l}7 \\
5 \\
\end{array}$ & $\begin{array}{l}\text { Grammar } \\
\text { Literature }\end{array}$ & $\begin{array}{l}23 \\
14 \\
\end{array}$ \\
\hline
\end{tabular}

Note: Only the lessons which have videos more than 5 were addressed in this table. 


\section{Significance of the Study}

Chemistry is one of the most difficult lessons in high school. Making abstract topics concrete is really important for chemistry classes to be comprehended by students. At this point, teaching abstract topics have become easier by the help of new advancements in technology such as videos, simulations, and pictures and so forth. That is; e-contents could be used to support teaching and learning activities. One of the main reasons of establishing EBA portal was to provide e-contents to support educational settings. In that regard, there were 163 videos on EBA which were developed to support the chemistry classes. These videos are about several topics in chemistry and different type of videos can be also seen. For example, some of the videos are learning objects that have been produced to be reused over and over. Some of the videos are like documentary and rest of them are instructional videos. In the instructional videos, a teacher tells the lesson as ifs/he is in a real classroom in front of students. These videos could be used in educational activities but their examination is really important. Otherwise, students and teachers may not make use of them absolutely. Even more, unexpected learning outcomes may occur.

In the scope of the present study, instructional videos developed for high school chemistry classes are going to be examined in terms of Gagne' nine events of instruction. It can be seen in the literature that Gagne's nine events of instruction could be used for effective teaching. Research about this type of instruction shows positive contribution to teaching and learning process (Martin, Klein, and Sullivan, 2004; Nelson, 2000). This is why; examination based on nine events of instruction can show practitioner how effective lessons they developed and what can be gained after the classes. Moreover, improvements can be done to increase the quality of videos to reach more desirable learning outcomes.

\section{Research Questions}

The purpose of the study was to examine the instructional high school chemistry videos on EBA in line with Gagne's nine events of instruction. Based on this purpose, the research question of this study is;

- To what extent are the instructional high school chemistry videos on EBA appropriate in accordance with Gagne's nine events of instruction?

\section{Literature Review}

Videos have been used with many purposes since they were introduced. They were primarily developed for the business, entertainment sector, and then used in education (Bijnens et al., 2004).). Videos are composed of moving images and moving image technologies have been developed by the years: film, television, videotapes, videodisks, digital desktop video, multimedia, CD-ROM, videoconferencing, interactive TV, and web-based media (Bijnens et al., 2004). These technologies all have in common that they all have the chance of showing the moving image to students.

The use of video in education became famous with the advancements in technology and research showing the advantages of video use in education. Advancements in 
technology made the video use cheaper and easy to be used in educational environments. From static images to web streamed video (Bijnens et al., 2004), from low bandwidth to high bandwidth internet, from difficult distribution of videos to easy distribution of videos, the use of videos increased. There have been many studies showing the benefits of using video in education. According to three 'I's framework of Young and Asensio (2002), while just using images gives the focus of control to teachers, using both images and interactivity gives the focus of control to students by giving them to the chance of access to media independent of location, the choice of a huge library of materials to view on-demand and control over the video. Thus, the videos on EBA portal can be more proper to constructivism model rather than the models which assert transmission the knowledge. The use of videos can help promote a student-centered environment where the students are learning by doing; as well as promoting a more critical awareness of their consumption of media products. (Masats, Dooly, 2011).

Jarvis and Dickie (2009) have stated that the use of video podcasts seems to foster more effective learning and supportive for students. In addition to that, they have found that the use of videos for class increase the quality of lesson. Hill and Nelson (2011) found that the use of videos are effective in terms of fostering learning and supporting teaching in their study related with employment of video podcasts. The Corporation for Public Broadcasting (CPB, 2004) has carried out a research about educational videos and they have found that educational videos enhance student comprehension, increase student motivation and promote teacher effectiveness (as cited in Holtzblatt, Tschakert, 2011). Whatley and Ahmad (2007) stated that video can be a powerful teaching medium to grab students' attention and can also be a strong motivator for learning. (as cited in Chan, 2010). Berk (2009) stated that the use of videos in teaching may be most appropriate for introductory courses, introducing complex topics in any course, lower achieving students, and visual/spatial learners since the use both verbal and visual material as in videos is most effective for novices and visual learners according to results of Mayer's research. In summary, previous research suggests that video have a positive impact on student attitudes, behavior, and learning performance (Kayand Kletskin, 2012). That is; using videos in educational settings are effective and supportive and even more students are keen on using videos as a part of their learning. Berk (2009) summarized the benefits of video use in classroom as videos are able to:

- Grab students' attention,

- Focus students' concentration,

- Generate interest in class,

- Create a sense of anticipation,

- Energize or relax students for learning exercise,

- Draw on students' imagination,

- Improve attitudes toward content and learning,

- Build a connection with other students and instructor,

- Increase memory of content,

- Increase understanding and foster creativity,

- Stimulate the flow of ideas and foster deeper learning,

- Provide an opportunity for freedom of expression,

- Serve as a vehicle for collaboration,

- Inspire and motivate students and make learning fun, 
- Set an appropriate mood or tone and decrease anxiety and tension on scary topics,

- Create memorable visual images.

All in all, videos could be used as supportive tool for educational activities. Benefitting from them could lead the desirable learning outcomes in the process of learning and teaching. Gagne was one of the most known educational specialists who brought all phases of the learning into instruction from setting goal to assessing performance (Smith \& Ragan, 2000). The phases of the instruction and internal mental processes were tabulated in Table 2 (Kruse, 2010). In the literature, there are studies that showed the validation of Gagne's nine events of instruction. For example Martin, Klein, and Sullivan (2004) argued in their study that instructions which used all phases of the learning significantly improved students' attitude to the courses when compared to the studies that left out some of the phase of it. Richey (2000) stated that Gagne's approach "is foundational to most instructional design models and is, by and large, still dominant among current designers who have been formally trained in the field" (p. 271). It can be seen in the literature that Gagne's nine events of instruction could be used for effective teaching. Research about this type of instruction shows positive contribution to teaching and learning process (Nelson, 2000). This is why; examination based on nine events of instruction can show practitioner how effective lessons they have developed and what can be gained after the classes. Moreover, improvements can be done to increase the quality of videos to reach more desirable learning outcomes.

Table 2. The Phases of Nine Events of Instruction

\begin{tabular}{ll}
\hline Instructional Event & Internal Mental Process \\
\hline Gain attention & Stimuli activates receptors \\
Inform learners of objectives & Creates level of expectation for learning \\
Stimulate recall of prior learning & Retrieval and activation of short-term memory \\
Present the content & Selective perception of content \\
Provide "learning guidance" & Semantic encoding for storage long-term memory \\
Elicit performance (practice) & Responds to questions to enhance encoding and \\
& verification \\
Provide feedback & Reinforcement and assessment of correct \\
& performance \\
Assess performance & Retrieval and reinforcement of content as final \\
& evaluation \\
Enhance retention and transfer to the job & Retrieval and generalization of learned skill to new situation \\
\hline
\end{tabular}

\section{Method}

In this study, content analysis was used to examine what extent the instructional high school chemistry videos on EBA are appropriate in accordance with Gagne's nine events of instruction. Krippendorff (2004) defined content analysis as "a systematic reading of a body of texts, images, and symbolic matter, not necessary from an author's or user's perspective" (p.3). To Fraenkel, Wallen and Hyun (2011), "Content analysis is a technique that enables researchers to study human behavior in an indirect way, through an analysis of their communications (p. 478). Communication here refers to the message conveyed by various things like pottery, textbooks, essays, newspapers, novels, magazine articles, cookbooks, songs, political speeches, advertisements and pictures which are not intentionally designed as communications but subsequently have been regarded in this way (Fraenkel et al., 2011).Although most of the studies focused on text format, it is also possible to conduct content analysis with picture or video based data. This type of analysis is called as "media content analysis" which was regarded as a 
specialized sub form of content analysis in the literature. Lasswell, Lerner and Pool (1952) summarize media content as:

- Who says what

- Through which channel

- To whom

- And with what effect (as cited in Shoemaker and Reese, 1996, p.12).

Content analysis can be conducted in both quantitative and qualitative ways. However there are disagreements among researchers about which of them is more appropriate (Sepstrup, 1981). Generally quantitative methods can determine how many acts of phenomena appear whereas qualitative approach refers to the nature of the phenomenon or how the phenomenon is conceptualized (Wotherspoon, 1988). A quantitative media content analysis was adopted as method of design considering the scope and aim of study.

\section{Sampling}

The sampling procedure used for the study is purposeful sampling. Purposeful sampling is selecting information-rich cases in order to better understand the phenomena (Patton, 1990).Being one of the most difficult and abstract disciplines, chemistry was purposefully selected for the evaluation. The related discipline was also considered to be the closest domain to the real life context and it would be more applicable to Gagne's nine events of instruction. To evaluate the appropriateness of the instructional videos on EBA in accordance with Gagne's nine events of instruction, four instructional designers who are experts in the field come together. Simply two different equal groups were formed. Both of two groups independently evaluated the qualities of the videos according to phases of Gagne's Nine Events of Instruction. Totally 13 instructional videos were evaluated by two groups being independent of each other $(\mathrm{N}=$ 26).

\section{Instrumentation and Scoring}

A scoring rubric was developed by the researchers in order to evaluate the quality of each video on the basis of the Gagne's nine events of instruction (see APPENDIX A). Each learning phase in the instructional videos were checked and scored by the experts to check what extent the phase is appropriate to Gagne's related events of instruction. The following criterion was used for the evaluation:

- 1 point, if the phase is unsatisfactory

- 2 points, if the phase needs improvements

- 3 points, if the phase is satisfactory

For example if the phase of "gain attention" in video1 is appropriate to Gagne's norms, it was rated as " 3 " by one expert group. The other expert group also evaluated the appropriateness of the same phase of the same video. Both the results of two expert groups were presented in the result section of the study.

\section{Results}

A quantitative media content analysis was applied in this study in order to understand what extent the instructional high school chemistry videos on EBA are appropriate in accordance with Gagne's nine events of instruction. The number of instructional high school chemistry videos on EBA portal was found as 13 at the time 
this study was being conducted. Some of the videos were separated into two parts. Thus, those videos were evaluated as if they were a whole video. The videos were evaluated by two groups consisting of two instructional designers according to a rubric developed by the researchers. Table 3 (see APPENDIX B) shows the videos and their scores examined by two groups for each phase of Gagne's nine events of instructions. For the gain attention phase, almost all of the videos applied this phase to some extent except only one video. This shows that almost all videos gained students' attention at the beginning. As for informing learner of the objective phase, while two videos did not apply this phase, the others applied this phase at least to some extent. The most problematic phase is stimulating recall of prerequisites since almost half of the videos did not apply this phase. Therefore, it can be said that students were not informed about what they need to know before watching half of the videos. This may also due to that videos were prepared in not a logical order, in a random order. Presenting stimulus material and providing learning guidance phases are the most applied phases for almost all of the videos to some extent. It can be said that these phases were considered as either needs to improve or satisfactory by the two groups of experts. Eliciting performance and providing feedback phases have the most controversy scores between two groups. While one group stated that five videos out of thirteen were applied these phases to some extent, the other group stated that they were not applied any. In addition, the means for these phases across all videos are same. For the last two phases, assessing performance and enhancing retention and transfer, the scores given by two groups were almost unsatisfactory for almost all videos. This means that the videos do not help students in terms of how much they learned and how they could remember what they learned later. The means for all phases in each video on group basis were also examined. Although the scores of videos in each phase may vary between two groups, the differences were not so much. According to first group, all of the videos were needed to be improved in terms of Gagne's nine events of instruction when considering the overall mean on video basis. On the other hand, three videos were problematic in terms of Gagne's nine events of instruction and they can be considered as unsatisfactory according to second group. According to results of two groups, all videos were needed to be revised and their quality were needed to be improved.

\section{Discussion}

The purpose of this study was to examine the instructional high school chemistry videos on EBA portal in terms of Gagne's nine events of instruction. Using videos for educational purposes have several positive contributions to both learning and teaching process (Choi and Johnson, 2010; Jarvis and Dickie, 2009; Hill and Nelson, 2011). Considering that, the instructional videos on EBA may have several benefits to the educational settings. In that regard, preparing these videos in accordance with Gagne's nine events of instructions may increase the possibility of success to foster teaching and learning process (Nelson, 2000; Martin, Klein and Sullivan, 2004). This is why; examination of videos in accordance with Gagne's nine events of instruction could be really important. In this study, results showed that most of the videos should be needed to be improved in terms of Gagne's nine events of instruction. For the first group of instructional designers, they rated thirteen videos by the help of the rubric and found that all of the videos are needed to be improved according to mean of all phases of nine events of instructions for each video. Similarly, second group rated thirteen videos and stated that ten of videos are needed to be improved and three of videos are unsatisfactory according to mean of all phases of nine events of instructions for each 
video. As it can be understood from the examination, the videos are needed to be improved in terms of Gagne's nine events of instruction. Stemler (1997) also stated that educators should design the educational materials appropriately that they can benefit from the potential of multimedia capabilities. Considering that; findings indicate that there is a need to improve the quality of chemistry videos on EBA. The videos about chemistry classes may not promote learning and teaching process. By improving the videos, as Nelson (2000) pointed out, effective instruction could be served to students.

Thirteen videos were examined on phase basis, as well. In other words, the first group said that gaining attention, informing learners of the objectives, eliciting performance, providing feedback of videos should be needed to be improved. In addition to these; stimulating recall of prerequisites, assessing performance and enhancing retention and transfer of videos are unsatisfactory. Presenting stimulus material and providing learning guidance of videos are satisfactory. Similarly, second group said that gaining attention, informing learner of the objectives, stimulating recall of prerequisites, providing learner guidance, eliciting performance and providing performance should be needed to be improved. Only presenting stimulus material is satisfactory and assessing performance and enhancing retention and transfer is unsatisfactory. On phase basis, it could be said for both group that some of events are missing or needs to be improved. For example; assessing performance and enhancing retention and transfer are unsatisfactory. That is; these two events on the videos have not been done appropriately and even more they are missing. The rest of the events are in need of improvement apart from presenting stimulus material. Based on the descriptive information, it could be concluded that videos are not appropriate in terms of Gagne's nine events of instruction. If the videos had been prepared in line with this instruction, effective instruction could have been provided to the students and better learning outcomes could be come out. Martin, Klein and Sullivan (2004) claimed that instructions in which all phases of nine events of instruction can significantly improve student's attitude toward their lessons. It can be concluded from this research that instructional high school chemistry videos on EBA may not be enough to improve positive attitude to the lessons. Because, some phases of nine events of instruction are missing or needed to be improved. Correspondingly; the videos may not help students improve positive attitudes toward lessons and foster teaching and learning process due to the missing points in phases.

\section{Limitations}

There are several educational content on the EBA web portal. Videos are just one of them. It includes several videos related with several topics. There is also different type of videos like instructional videos, documentaries and learning objects. In this study, only instructional videos were chosen to be examined in accordance with Gagne's nine events of instruction. The examination of instructional videos is limited to high school chemistry lesson. The other instructional videos belonging to different courses were not examined in the scope of present study. The score differences between groups may be because of the evaluators' point of view while evaluating the videos for each phase. 


\section{References}

Berk, R. A. (2009). Multimedia teaching with video clips: TV, movies, YouTube and $\mathrm{mtv} \mathrm{U}$ in the college classroom. International Journal of Technology in Teaching and Learning, 5(1), 1-21.

Bijnens, M., Vanbuel, M., Verstegen, S., \& Young, C. (2004). Handbook on digital video and audio in education. Retrieved from http://www.videoaktiv.orgon June $12^{\text {th }} 2013$.

Chan, Y. M. (2010). Video instructions as support for beyond classroom learning. Procedia - Social and Behavioral Sciences, 9, 1313-1318.

Choi, H. J., \& Johnson, S. D. (2010). The Effect of Context-Based Video Instruction on Learning and Motivation in Online Courses. American Journal of Distance Education, 19(4), 215-227.

EBA(2013). Eğitimde Bilişim Ağı Nedir. Retrieved from http://www.eba.gov.tr/hakkinda on May $25^{\text {th }} 2013$.

Fraenkel, J., Wallen, N., \& Hyun, H. (2011). How to design and evaluate research in Education (8th ed). Columbus, OH: McGraw-Hill

Godfrey, C. (2001). Computers in school: Changing technologies. Australian Educational Computing, 16(2), 14-17.

Holtzblatt, M., \& Tschakert, N. (2011). Expanding your accounting classroom with digital video technology. Journal of Accounting Education, 29, 100-121.

Kay, R., \& Kletskin, I. (2012). Evaluating the use of problem-based video podcasts to teach mathematics in higher education. Computers \& Education, 59(2), 619627.

Krippendorff, K. (2012). Content analysis: An introduction to its methodology. SAGE Publications, Incorporated.

Kruse, K. (2010). Gagné's nine events of instruction: An Introduction. Retrieved May 27, 2013 from http://www.e-learningguru.com/articles/art3_3.htm

Masats, D., \& Dooly, M. (2011). Rethinking the use of video in teacher education : A holistic approach. Teaching and Teacher Education, 27(7), 1151-1162.

Martin, F., Klein, J. D. \& Sullivan, H. (2004, October). Effects of instructional events in computer-based instruction. Proceedings of the Association for Educational Communications and Technology, Chicago, IL.

Ministry of National Education (MEB). (2013). Fatih Project. Retrieved May 28, 2013 from http://fatihprojesi.meb.gov.tr/tr/english.php

Nelson, W. (2000). Gagné and the new technologies of instruction. In R. Richey (Ed.), Legacy of Robert M. Gagné (pp. 229 - 251). Retrieved on June 1, 2013, fromhttp://www.eric.ed.gov/PDFS/ED445674.pdf

Patton, M. (1990). Qualitative Evaluation and Research Methods. Thousand Oaks, California: Sage Publications, Inc.

Richey, R. C. (Ed.). (2000).The legacy of Robert M. Gagné. Syracuse, NY: ERIC Clearinghouse on Information and Technology.

Sepstrup, P. (1981). Methodological developments in content analysis?, Advances in content analysis, ed. K.E. Rosengren, 9, Sage annual reviews of communication research, Sage, Beverly Hills, California.

Shoemaker, P. \& Reese, S. (1996). Mediating the message: theories of influences on mass media content. White Plains, NY: Longman.

Smith, P., \& Ragan, T. (2000). The impact of R. M. Gagné's work on instructional theory. In Richey, R. (Ed.). Legacy of Robert M. Gagné (pp. 225-281). 
Retrieved from

http://ibstpi.org/_dev/archived/backup/Products/pdf/chapter_6.pdf

Stemler, L. K. (1997). Educational Characteristics of Multimedia : A Literature Review. Journal of Educational Multimedia and Hypermedia, 6, 339-259.

Wotherspoon, D. K. (1988). Television Content Analysis: Agreement between Expert and Naive Coders. The University of British Columbia.

Young, C., \& Asensio, M. (2002). Looking through three "I"s: the pedagogic use of streaming video. In S. Banks, P. Goodyear, V. Hodgson, \& D. McConnell (Eds.), Networked Learning (pp. 628-635). Sheffield. 
APPENDIX A

Rubric for Evaluating Instructional Videos on EBA Portal according to Gagne's Nine Events of Instruction

\begin{tabular}{|c|c|c|c|}
\hline $\begin{array}{l}\text { Nine Events of } \\
\text { Instruction }\end{array}$ & $\begin{array}{l}\text { Unsatisfactory } \\
\text { (1) }\end{array}$ & $\begin{array}{l}\text { Needs to Improve } \\
\text { (2) }\end{array}$ & $\begin{array}{l}\text { Satisfactory } \\
\text { (3) }\end{array}$ \\
\hline Gain Attention & $\begin{array}{l}\text { Gaining attention is missing or } \\
\text { incomprehensible }\end{array}$ & $\begin{array}{l}\text { Gaining attention is somewhat } \\
\text { unclear or not good enough }\end{array}$ & $\begin{array}{l}\text { Presenting a good problem, a new } \\
\text { situation or a novel idea to gain } \\
\text { attention }\end{array}$ \\
\hline $\begin{array}{l}\text { Informing } \\
\text { Learner of the } \\
\text { Objective }\end{array}$ & $\begin{array}{l}\text { Fails to inform about the } \\
\text { objectives of lesson or not } \\
\text { mention about the objectives }\end{array}$ & $\begin{array}{l}\text { Objectives of the lesson is } \\
\text { somewhat unclear or incomplete }\end{array}$ & $\begin{array}{l}\text { Stating clear and accurate } \\
\text { objectives of the lesson }\end{array}$ \\
\hline $\begin{array}{l}\text { Stimulate Recall } \\
\text { of prerequisites }\end{array}$ & $\begin{array}{l}\text { No recalling about previous } \\
\text { learning or irrelevant recalling }\end{array}$ & $\begin{array}{l}\text { Recalling previous learning but } \\
\text { somehow missing or unclear }\end{array}$ & $\begin{array}{l}\text { Recalling previously acquired } \\
\text { capabilities just before the new } \\
\text { learning takes place. }\end{array}$ \\
\hline $\begin{array}{l}\text { Presenting the } \\
\text { stimulus Material }\end{array}$ & $\begin{array}{l}\text { Fails to present the accurate, } \\
\text { coherent or stimulus material and } \\
\text { content }\end{array}$ & $\begin{array}{l}\text { Presenting the content or material } \\
\text { with lack of clarity or coherence }\end{array}$ & $\begin{array}{l}\text { Presenting accurate and } \\
\text { coherent content in a well- } \\
\text { organized way }\end{array}$ \\
\hline $\begin{array}{l}\text { Providing } \\
\text { Learning } \\
\text { Guidance }\end{array}$ & $\begin{array}{l}\text { Fail to provide additional } \\
\text { guidance such as clear } \\
\text { instructions, directions, extra } \\
\text { examples or not encouraging the } \\
\text { students }\end{array}$ & $\begin{array}{l}\text { Assisting learning with additional } \\
\text { guidance is somewhat missing or } \\
\text { unclear. }\end{array}$ & $\begin{array}{l}\text { Additional guidance such as clear } \\
\text { instructions, directions, extra } \\
\text { examples were given, } \\
\text { encouraging the students. }\end{array}$ \\
\hline $\begin{array}{l}\text { Eliciting } \\
\text { Performance }\end{array}$ & $\begin{array}{l}\text { Not enabling students to show } \\
\text { their performance }\end{array}$ & $\begin{array}{l}\text { Something is missing/unclear in } \\
\text { enabling students to show their } \\
\text { performance }\end{array}$ & $\begin{array}{l}\text { Enabling students to show their } \\
\text { performance during the lesson }\end{array}$ \\
\hline $\begin{array}{l}\text { Providing } \\
\text { Feedback }\end{array}$ & $\begin{array}{l}\text { Not informing students about the } \\
\text { degree of } \\
\text { correctness/appropriateness of } \\
\text { their performance }\end{array}$ & $\begin{array}{l}\text { Informing the students about their } \\
\text { performance is somewhat missing } \\
\text { or not enough. }\end{array}$ & $\begin{array}{l}\text { Students were informed about the } \\
\text { degree of } \\
\text { correctness/appropriateness of } \\
\text { their performance in a clear way. }\end{array}$ \\
\hline $\begin{array}{l}\text { Assessing } \\
\text { Performance }\end{array}$ & $\begin{array}{l}\text { Teacher did not assess the } \\
\text { student's performance by } \\
\text { collecting formal/convincing } \\
\text { evidence }\end{array}$ & $\begin{array}{l}\text { Assessing student's performance } \\
\text { is missing or not enough. }\end{array}$ & $\begin{array}{l}\text { Teacher assessed the student's } \\
\text { performance by collecting formal } \\
\text { and convincing evidence }\end{array}$ \\
\hline $\begin{array}{l}\text { Enhancing } \\
\text { Retention and } \\
\text { Transfer }\end{array}$ & $\begin{array}{l}\text { Not enhancing and ensuring } \\
\text { learner's understanding by giving } \\
\text { new tasks }\end{array}$ & $\begin{array}{l}\text { Enhancing and ensuring learner's } \\
\text { understanding is somewhat } \\
\text { unclear or not good enough }\end{array}$ & $\begin{array}{l}\text { Enhancing and ensuring learner's } \\
\text { understanding by giving new } \\
\text { tasks }\end{array}$ \\
\hline
\end{tabular}




\section{APPENDIX B}

\section{Table 3}

The videos and their scores given by two groups according to Gagne's nine events of instruction

\begin{tabular}{|c|c|c|c|c|c|c|c|c|c|c|c|c|c|c|c|c|c|c|c|c|}
\hline \multirow{2}{*}{$\begin{array}{l}\text { Gagne's Nine Events of Instruction } \\
\text { Video Name }\end{array}$} & \multicolumn{2}{|c|}{$\begin{array}{l}\text { Gain } \\
\text { Attention }\end{array}$} & \multicolumn{2}{|c|}{$\begin{array}{l}\text { Informing } \\
\text { Learner of } \\
\text { the } \\
\text { Objective }\end{array}$} & \multicolumn{2}{|c|}{$\begin{array}{l}\text { Stimulate } \\
\text { Recall of } \\
\text { prerequisites }\end{array}$} & \multicolumn{2}{|c|}{$\begin{array}{l}\text { Presenting } \\
\text { Stimulus } \\
\text { Material }\end{array}$} & \multicolumn{2}{|c|}{$\begin{array}{l}\text { Providing } \\
\text { Learning } \\
\text { Guidance }\end{array}$} & \multicolumn{2}{|c|}{$\begin{array}{l}\text { Eliciting } \\
\text { Performance }\end{array}$} & \multicolumn{2}{|c|}{$\begin{array}{l}\text { Providing } \\
\text { Feedback }\end{array}$} & \multicolumn{2}{|c|}{$\begin{array}{l}\text { Assessing } \\
\text { Performance }\end{array}$} & \multicolumn{2}{|c|}{$\begin{array}{l}\text { Enhancing } \\
\text { Retention } \\
\text { and } \\
\text { Transfer } \\
\end{array}$} & \multicolumn{2}{|c|}{$\begin{array}{l}\text { Overall } \\
\text { Mearn on } \\
\text { Video } \\
\text { Basis } \\
\end{array}$} \\
\hline & $G 1$ & $G 2$ & $G 1$ & $G 2$ & $G 1$ & $G 2$ & $G 1$ & $G 2$ & $G 1$ & $G 2$ & $G 1$ & $G 2$ & $G 1$ & $G 2$ & $G 1$ & $G 2$ & $G 1$ & $G 2$ & $G 1$ & $G 2$ \\
\hline Iyonik Bilesikler-1-2 & 2 & 1 & 2 & 2 & 1 & 2 & 3 & 2 & 2 & 1 & 1 & 1 & 2 & 1 & 1 & 1 & 1 & 1 & 1.67 & 1.33 \\
\hline Kimyanin Temel Kanunlari - 1-2 & 2 & 3 & 1 & 1 & 1 & 2 & 2 & 2 & 3 & 2 & 2 & 2 & 2 & 2 & 1 & 1 & 1 & 1 & 1.67 & 1.78 \\
\hline Bilesikler Nasil Olusur - 1-2 & 1 & 1 & 3 & 2 & 2 & 3 & 2 & 2 & 2 & 3 & 2 & 2 & 2 & 2 & 1 & 1 & 1 & 1 & 1.78 & 1.89 \\
\hline Insan Madde Iliskilerinin Tarihçesi & 3 & 3 & 2 & 2 & 1 & 3 & 3 & 3 & 3 & 3 & 3 & 2 & 2 & 2 & 1 & 1 & 1 & 1 & 2.11 & 2.22 \\
\hline Atom ve Elektrik - 1-2 & 3 & 2 & 3 & 2 & 1 & 2 & 3 & 3 & 3 & 2 & 3 & 2 & 3 & 2 & 1 & 1 & 1 & 1 & 2.33 & 1.89 \\
\hline Atom Modelleri & 2 & 2 & 1 & 1 & 1 & 1 & 3 & 2 & 3 & 2 & 3 & 1 & 3 & 1 & 1 & 1 & 1 & 1 & 2.00 & 1.33 \\
\hline Iç Enerji Isi ve Is Kavramlari & 3 & 2 & 2 & 2 & 1 & 1 & 3 & 2 & 3 & 1 & 3 & 1 & 3 & 1 & 1 & 1 & 2 & 1 & 2.33 & 1.33 \\
\hline $\begin{array}{l}\text { Tepkime Hizi Bagintisinin Yazilmasi ve } \\
\text { Derisimin Hiz Üzerindeki Etkisi-1 }\end{array}$ & 3 & 3 & 2 & 2 & 1 & 1 & 3 & 3 & 3 & 2 & 2 & 1 & 3 & 1 & 1 & 1 & 2 & 1 & 2.22 & 1.67 \\
\hline Tepkime Hizi ve Hiza Etki Eden Faktörler-2 & 2 & 1 & 3 & 2 & 1 & 2 & 2 & 3 & 2 & 2 & 2 & 1 & 1 & 1 & 1 & 1 & 2 & 1 & 1.78 & 1.56 \\
\hline Sistemler ve Enerji Türleri & 3 & 3 & 2 & 1 & 1 & 1 & 3 & 3 & 3 & 1 & 3 & 2 & 3 & 2 & 1 & 1 & 2 & 1 & 2.33 & 1.67 \\
\hline Elementler Kimyasi-1-2 & 2 & 2 & 3 & 2 & 1 & 1 & 3 & 3 & 2 & 2 & 1 & 2 & 1 & 2 & 1 & 1 & 1 & 1 & 1.67 & 1.78 \\
\hline Evrende ve Dünyada Elementler-1-2 & 2 & 2 & 3 & 2 & 1 & 2 & 2 & 3 & 2 & 2 & 2 & 3 & 2 & 2 & 2 & 1 & 1 & 1 & 1.89 & 2.00 \\
\hline Alasimlar - 1-2 & 2 & 3 & 3 & 2 & 1 & 1 & 2 & 3 & 3 & 3 & 1 & 1 & 2 & 1 & 1 & 1 & 1 & 1 & 1.78 & 1.78 \\
\hline Overall Mean on Phase Basis & 2.31 & 2.15 & 2.31 & 1.77 & 1.08 & 1.69 & 2.62 & 2.62 & 2.62 & 2.00 & 2.15 & 1.62 & 2.23 & 1.54 & 1.08 & 1.00 & 1.31 & 1.00 & & \\
\hline
\end{tabular}

Notes: G1 refers scores of First Group, G2 refers scores of Second Group

1 = Unsatisfactory, $2=$ Needs to improve, $3=$ Satisfactory 